\title{
The forgotten history of pre-modern epidemiology: contribution of Ibn An-Nafis in the Islamic golden era
}

Ghazi Kayali ${ }^{1,2}$

\section{Introduction}

Hippocrates (around 460-370 BCE) was a Greek physician and philosopher who is considered the father of modern medicine (Figure 1). The history of epidemiology typically starts with Hippocrates in about 400 BCE but then more than 2000 years are skipped until the birth of modern epidemiology in the 17 th century CE with the work of John Graunt, followed by William Farr and John Snow in the 19th century (1). However, between the time of Hippocrates and the 17th century, the Islamic golden age of science occurred (8th-16th century CE) (2).

This work attempts to fill this gap of 2000 years by tracing the contributions of Muslim scientists to the field of epidemiology. The epidemiological concepts described by Hippocrates are highlighted followed by a discussion of how his work influenced the work of Muslim scientists, in particular Ibn AnNafis, who preserved and advanced the field until the European Renaissance.

\section{Hippocrates}

In his book, Of the Epidemics (3), Hippocrates introduced several concepts of epidemiology that are considered the fundamentals of modern epidemiology. His main thesis was that disease causality can be attributed to climate, seasonal variations and location. $\mathrm{He}$ noted that habits, regimens and personal pursuits are all factors associated with disease occurrence. His book included a description of the disease prognosis of several patients. Hence, this was the first epidemiology work to present case series, a modern design for observational studies. For most of the cases, he provided information about age, gender, place of residence and the seasonal conditions at the time of onset of the illness. After describing the symptoms, Hippocrates described the outcome in terms of morbidity and mortality. $\mathrm{He}$ also discussed disease modes of transmission and recognized that certain "genetic" predispositions could lead to disease. This was evident when he discussed the case of a feverish woman whose symptoms were brought on by eating grapes and who had a "congenital tendency to phthisis". Illness of another two cases was attributed to drinking and sexual indulgence. The case of Apollonius was clearly a foodborne episode as Hippocrates states that, "Having eaten beef, and drunk unseasonably, he became a little heated at first, and betook himself to bed, and having used large quantities of milk, that of goats and sheep, and both boiled and raw, with a bad diet otherwise, great mischief was occasioned by all these things."

In another book, On Airs, Waters and Places (4), Hippocrates presented the thesis that diseases should be studied in light of the season in which they happen, the quality of the available water and the prevailing environmental conditions. Hippocrates drew a distinction between epidemic and endemic diseases. $\mathrm{He}$ explained that a good physician, "as the season and the year advances, he can tell what epidemic diseases will attack the city, either in summer or in winter, and what each individual will be in danger of experiencing from the change of regimen". Hence, he introduced the concept of endemicity in contrast to epidemic diseases that occur out of the routine. He associates endemicity with the climatic conditions of each region.

Another important concept in this book is the association of place, water and food with physical and emotional health. Hippocrates observed that a person's diet and alcohol consumption were directly associated with disease. He further observed that people with sedentary lifestyles tended to be more obese and those who were obese typically had reproductive health problems. He directly attributed certain diseases to poor water quality. Stagnant waters were directly linked to the occurrence of diarrhoea and dysentery, especially in the summer, while consumption of water with a high mineral content was directly attributed to having kidney problems.

\section{Ibn An-Nafis}

The Muslim-Arab physician Alaa AlDin Ali Ibn Abi Al-Hazm Al-Qurashi Al-Demashki Al-Masri El-Safii, better known as Ibn An-Nafis, was born in Damascus, Syria in 1210 CE (Figure 1) (5-7). He spent the first half of his life in Damascus where he studied medicine. He then settled in Cairo, Egypt where he practised at its largest hospital at the time, Al-Bimaristan Al-Nasiri (5). He 
lived for 78 years and died in Cairo in 1288 (5). His most influential work was in the field of medicine and he is credited with discovering the pulmonary blood circulation $(2,6,7)$. He is also credited with early work in cardiology $(8,9)$. However, his interests extended beyond medicine and included epidemiology, nutrition, Islamic religion and philosophy as evidenced by at least 24 books authored by him.

As a scholar, Ibn An-Nafis was influenced by the works of his predecessors. He studied the works of Ibn Sina (Avicenna, about 980-1037 CE), Al-Razi (Rhazes, about 865-925 CE), Galen (about 130-199 CE) and Hippocrates $(2,5,10)$. It is worthwhile mentioning here that the vast majority of the works of Hippocrates and Galen were translated into Arabic, especially by the Christian-Arab scholars Hanin Ibn Ishaq, Yuhanna Ibn Al-Batriq and Qusta Ibn Luqa (5). As an epidemiologist, Ibn An-Nafis was influenced by
Hippocrates and his most relevant work was A commentary on Hippocrates' "Of the Epidemics". Ibn An-Nafis also wrote A commentary on Hippocrates' Aphorisms based on the Aphorisms of Hippocrates where both authors, each in his own book, showed their prowess as early epidemiologists.

\section{A commentary on Hippocrates" "Of the Epidemics" (Sharh Kitab Al-Epidemia) (11)}

Hippocrates' book Of the Epidemics was translated into Arabic by Ibn Ishaq, based on which, Ibn An-Nafis wrote his commentary on Of the Epidemics. An ancient Arabic copy of this book dated $1215 \mathrm{AH}(1800-1801 \mathrm{CE})$ is available on microfilm at the Egyptian National Library and Archives in Cairo and was reviewed for this analysis (Figures 2 and 3). Ibn An-Nafis' book was not a mere translation of the original work by Hippocrates but rather a critical appraisal of it.

In the first constitution of Hippocrates' Of the Epidemics, Hippocrates opens with the phrase: "In Thasus, about the autumn equinox, and under the Pleiades...". Ibn An-Nafis opened his book by providing an explanation of why Hippocrates specified the location "Thasus" explaining that geographic location and not only climate is important when studying disease occurrence. Both scholars embraced the notion that imbalances in temperature and humidity were causes of disease, an accepted biological dogma in their times. However, Ibn An-Nafis tries to provide biological plausibility for this notion by giving a potential biological mechanism, according to the accepted biological concepts of the time, through which humidity can cause disease. Both scholars described the distribution of disease by
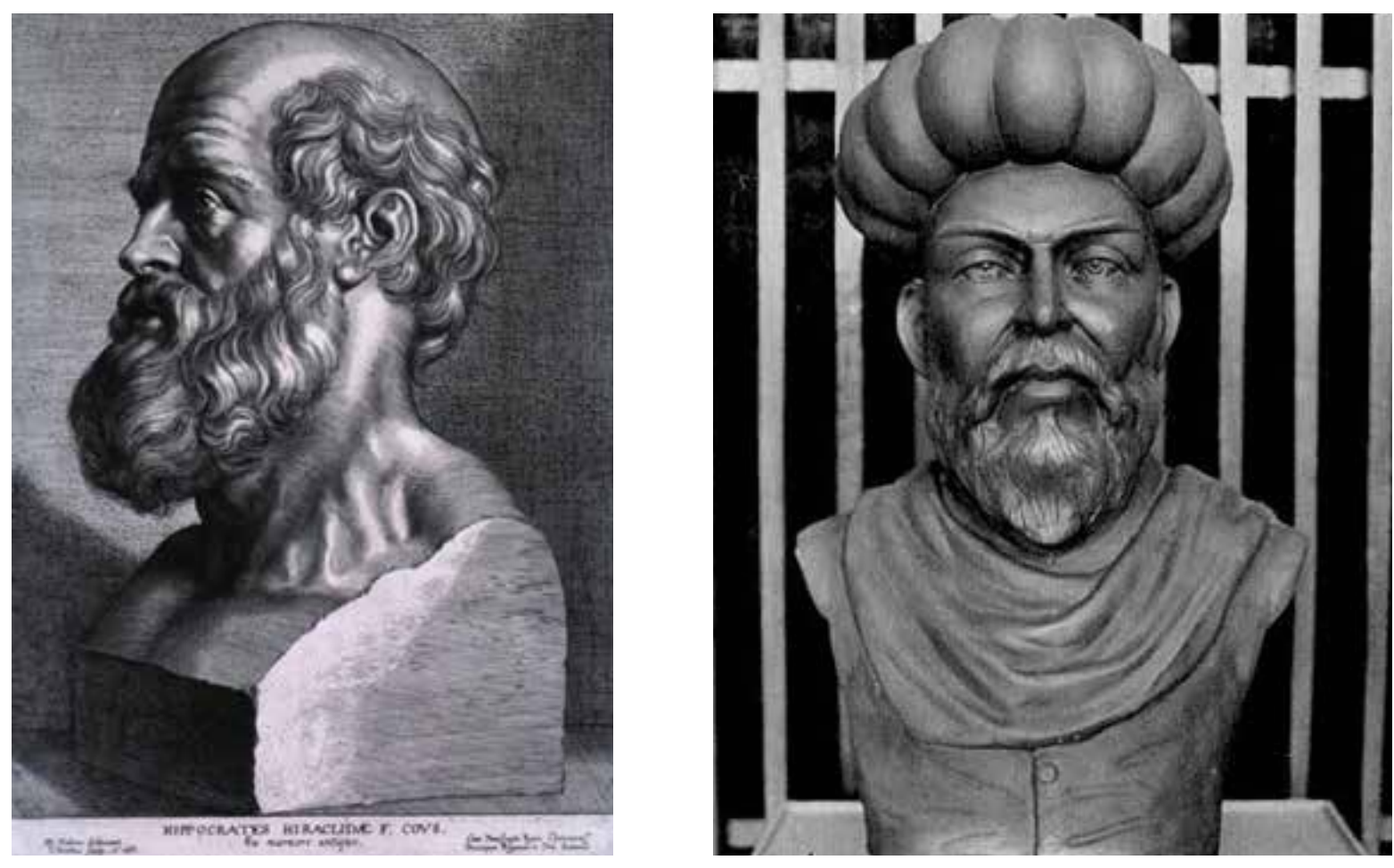

Figure 1 Hippocrates (left) and Ibn An-Nafis (right) 
demographic categories, but Ibn AnNafis explained that people of different ages and genders have different biological processes and occupational hazards that contribute to the onset of disease.

In his analysis of the second constitution, Ibn An-Nafis explained the exposure-outcome association laid down by Hippocrates. He provided a better definition of the seasons (exposure) using astrological signs, and then categorized outcome under several groups from mild to severe. An example here would be Ibn An-Nafis' categorization of respiratory illness from mild colds to tuberculosis.

In the explanation of the third constitution, the influence of Persian medical practice on Ibn An-Nafis is also evident. He uses the Persian term (bersam/sersam) to explain what Hippocrates meant by phrenitis (an inflammation of the body and mind). In this section, Hippocrates discussed seasonality of disease, changes in the elements, geographic distribution and associated risk factors and Ibn An-Nafis provided examples.

A significant portion of $O f$ the Epidemics is dedicated to describing a series of cases of illness. Ibn An-Nafis provided some biological explanations for the disease prognosis for some of those cases. In addition, Ibn An-Nafis used what Hippocrates described to compare and contrasts cases and outbreaks of diseases that he handled. For example, Ibn An-Nafis compares an outbreak of malnutrition in Damascus to that described by Hippocrates. Both scholars clearly describe the location of cases as if drawing an outbreak map as did John Snow hundreds of years later. In addition, Ibn An-Nafis described cases of anthrax, linking incidence to climate and demonstrating that when a person has minor uncovered wounds, there is a risk of infection that typically ends with death.

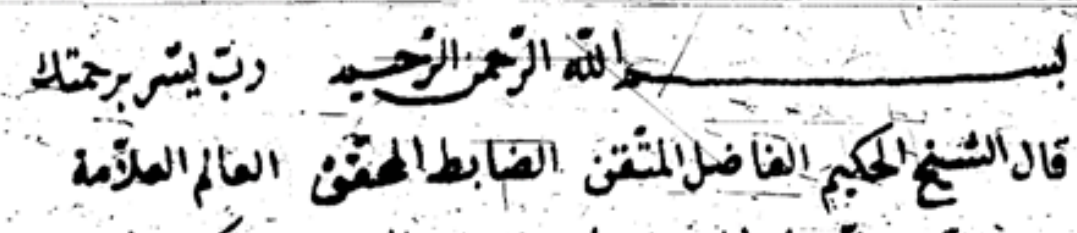

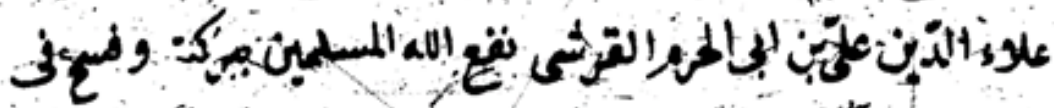

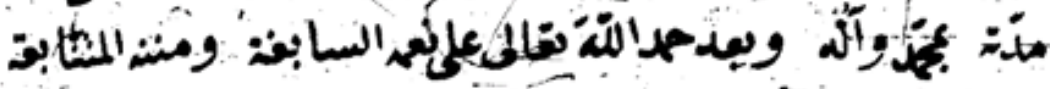

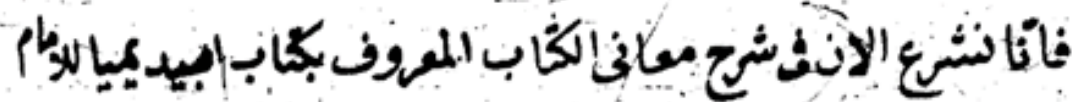

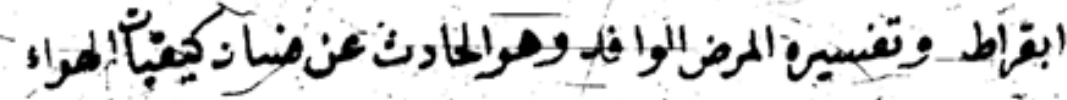

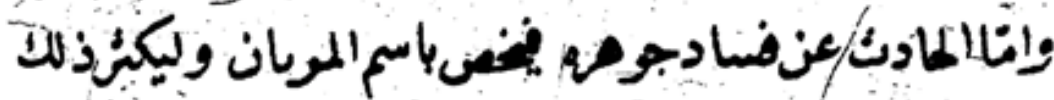

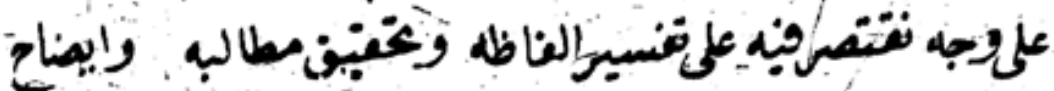

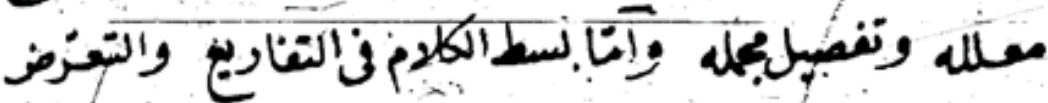

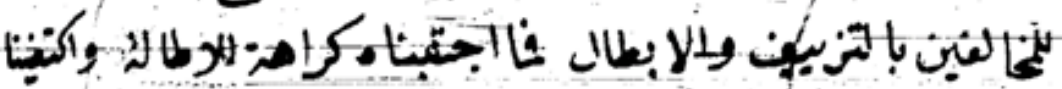

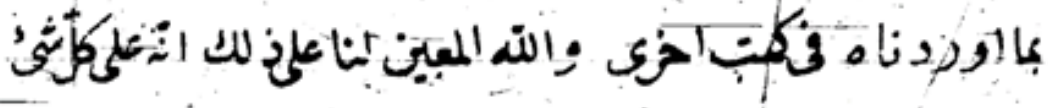

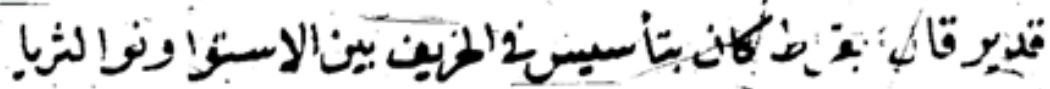

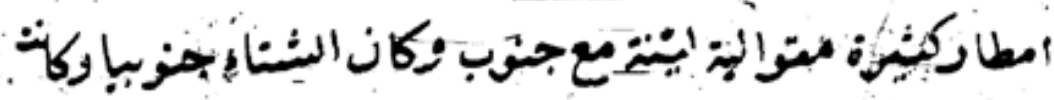

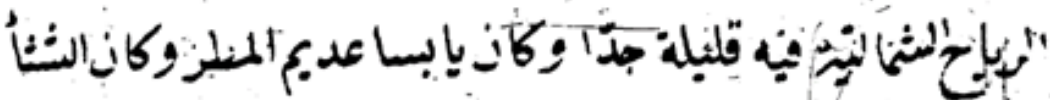

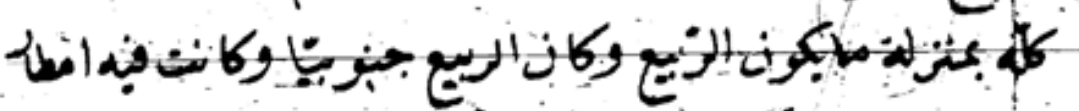

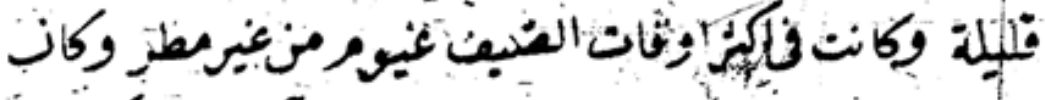

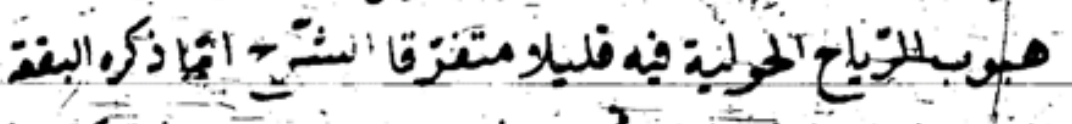

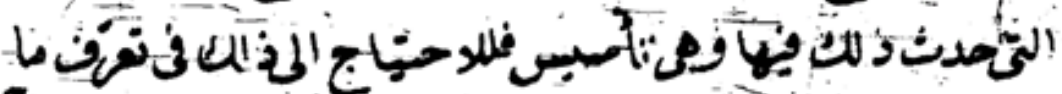

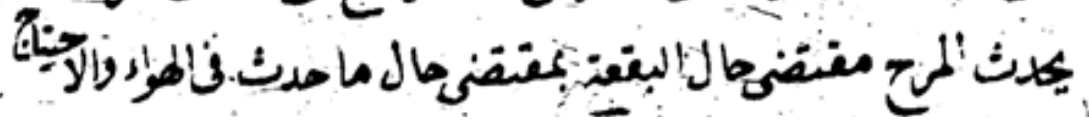

Figure 2 First page of Ibn An-Nafis book $A$ commentary on Hippocrates' "Of the Epidemics". An ancient Arabic language copy of this book, dated $1215 \mathrm{AH}$ (1800-1801 CE), at the Egyptian National Library and Archives in Cairo was reviewed for this manuscript. 


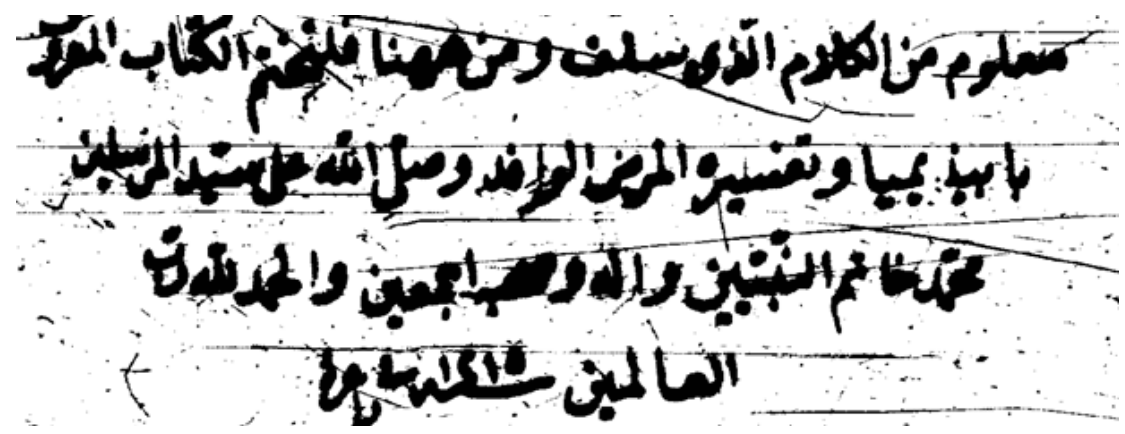

Figure 3 Last paragraph of Ibn An-Nafis book $A$ commentary on Hippocrates' "Of the epidemics".

A commentary
on Hippocrates'
Aphorisms (Sharh
Fusul Bocrat) (5)

Hippocrates' Aphorisms was translated by Ibn Ishaq and based on this translation Ibn An-Nafis wrote his commentary. Hippocrates discussed the role of seasonality, changes in climate, rain and wind on disease incidence. Ibn AnNafis attempted to provide biological plausibility to this by explaining how these factors affect different organs. For example, Ibn An-Nafis explained that winds may carry diseases hence demonstrating the occurrence of airborne respiratory illness. When discussing the role of location, Ibn An-Nafis explained that different disease patterns occur in different locations due to differences not only in climate but also in the body types of people living in different locations, hence suggesting the role genetics in disease predisposition.

\section{Conclusion}

Modern epidemiology was shaped by the work of 16th century scientists. However, when discussing the history of pre-modern epidemiology, discussing the work of Hippocrates only is a common mistake. Hippocrates remains the father of epidemiology but the field was a scholarly topic for Muslim scientists who excelled during the Islamic golden age between the 8 th and 16 th centuries
CE. Influenced by Hippocrates, these scholars, and in particular Ibn An-Nafis, moved the science of epidemiology forward. Hence, their work deserves to be credited. It becomes more plausible since the works of Hippocrates were preserved through their translation to Arabic and through the critical appraisals of them by Muslim scholars. Renaissance and modern era scientist then studied the Latin translations of Arabic works which led to the rise of modern epidemiology. Hence, the evolution of epidemiology, similar to other sciences, was a continuum that was contributed to by different civilizations in different eras.

\section{Acknowledgements}

I am grateful to Dr Youssef Ziedan for his guidance. Dr Ziedan is an Egyptian scholar specializing in Arabic and Islamic studies. He has directed a number of projects aimed at the delimitation and preservation of Arabic manuscripts. His academic work on documenting the works of Ibn An-Nafis and other Muslim scientists was crucial to the preparation of this manuscript.

\section{Funding: None}

Competing interests: None declared.

\section{References}

1. Prinicples of epidemiology in public health practice. Atlanta: Centers for Diesease Contriol and Prevention; 2012 (http:// www.cdc.gov/ophss/csels/dsepd/ss1978/lesson1/section2. html, accessed 27 Ocober 2017).

2. West JB. Ibn al-Nafis, the pulmonary circulation, and the Islamic Golden Age. J Appl Physiol. 2008; 105(6):1877-80.

3. Hippocrates. Of the epidemics. Kessinger Legacy Reprints. Montana: Kessinger Publishing; 2012.

4. Hippocrates. On airs, waters and places. Kessinger Legacy Reprints. Montana: Kessinger Publishing; 2009.

5. Abdel Kader M, Zeedan Y. Sharh Fusul Bocrat [A commentary on Hippocrates aphorisms]. Cairo: Al-Dar Al-Masriah AlLubnaniah; 1991 [In Arabic].

6. Akmal M, Zulkifle M, Ansari A. Ibn Nafis - a forgotten genius in the discovery of pulmonary blood circulation. Heart Views. 2010 Mar;11(1):26-30. PMID:21042463
7. Loukas M, Lam R, Tubbs RS, Shoja MM, Apaydin N. Ibn al-Nafis (1210-1288): the first description of the pulmonary circulation. Am Surg. 2008 May;74(5):440-2. PMID:18481505

8. Baharvand-Ahmadi B, Bahmani M, Zargaran A. Ibn Nafis and the early description of the role of coronary arteries in blood supply of the heart. Int J Cardiol. 2016 Feb 1;204:131-2. PMID:26657607

9. Numan MT. Ibn Al Nafis: his seminal contributions to cardiology. Pediatr Cardiol. 2014 Oct;35(7):1088-90. PMID:25096906

10. Lakhtakia R. A trio of exemplars of medieval Islamic medicine: Al-razi, Avicenna and Ibn Al-Nafis. Sultan Qaboos Univ Med J. 2014 Nov;14(4):e455-9. PMID:25364546

11. Ibn An-Nafis A. Sharh Kitab Al-Epidemia [A commentary on Hippocrates' Of the epidemics. Cairo: Dar El-Kotob Al-Masriah; before 1288 [In Arabic] 